\title{
Pulmonary Mass
}

National Cancer Institute

\section{Source}

National Cancer Institute. Pulmonary Mass. NCI Thesaurus. Code C35159.

An abnormal growth in the lung. 